\title{
PENGARUH KEMAMPUAN KOMUNIKASI INTERPERSONAL PENDAMPING SOSIAL DENGAN ANGGOTA KELOMPOK USAHA BERSAMA TERHADAP KINERJA USAHA EKONOMI PRODUKTIF DI KOTA BANJARMASIN
}

\author{
Muhammadun, Rahmi Widyanti, dan Basuki \\ madun_2015@gmail.com \\ Program Pascasarjana Ilmu Komunikasi, \\ Universitas Islam Kalimantan Muhammad Arsyad Al-Banjari Banjarmasin
}

\begin{abstract}
Sosial assistant interpersonal communication is a process of interpersonal interaction is done by social assistant with members of the Business Group (KUBE) in developing productive economic activities in the city of Banjarmasin by using verbal and non-verbal communication. Thesis research method is quantitative research. Place of research conducted in the city of Banjarmasin.

The research objective was to determine whether there is influence interpersonal communication skills are built between social companion with members UsahaBersama Group (KUBE) in developing productive economic activities in the city of Banjarmasin.

Our research found that there is a significant relationship between interpersonal communication skills with a social companion KUBE members in developing productive economic activities in the city of Banjarmasin through a cognitive approach. There is influence between interpersonal communication skills with a social companion KUBE members in developing productive economic activities in the city of Banjarmasin through emotional approach. There is a relationship between the ability komunikasi interpersonal social companion with KUBE members in developing productive economic activities in the city of Banjarmasin fun approach.

Suggestion of this research to the Social Welfare Office of South Kalimantan Province should be better in fostering the social companion and member of the Joint Business Group (KUBE) that will be established good cooperation in developing productive economic activities that already exist for more advanced and developed. Need further research to determine other factors that could affect the development of productive economic activities of members of the Joint Business Group (KUBE).
\end{abstract}

Keywords: Interpersonal Communication, Member of KUBE, Banjarmasin 


\section{PENDAHULUAN}

Untuk mewujudkan tujuan dari Program Penanggulangan Kemiskinan melalui KUBE perlu dilaksanakan pendampingan sosial oleh tenaga Pendamping Sosial/KUBE sebagai ujung tombak keberhasilan program dimaksud. Pendampingan Sosial merupakan suatu proses menjalin relasi sosial antara pendamping dengan anggota KUBE, dan masyarakat sekitarnya dalam rangka memecahkan masalah, memperkuat dukungan, mendayagunakan berbagai sumber dan potensi dalam pemenuhan kebutuhan hidup, serta meningkatkan akses anggota terhadap pelayanan sosial dasar, lapangan kerja dan fasilitas pelayanan publik lainnya. (Petunjuk Pelaksanaan Kelompok Usaha Bersama Direktorat Jenderal Pemberdayaan Sosial dan Penanggulangan Kemiskinan Kementerian Sosial RI 2014: 7).

Faktor utama suatu KUBE Maju, berkembang dan gagal ujung tombaknya ada di pendamping sosial. Berdasarkan Surat Keputusan Kepala Dinas Sosial Provinsi Kalimantan Selatan Nomor : 572 Tahun 2013, tentang Penunjukan Pendamping Sosial KUBE Provinsi, Kabupaten/Kota, Kecamatan, dan Kelurahan di Kota Banjarmasin, Tanggal 8 Mei 2013, fungsi dan tugasnya.

Sedangkan kendala lainnya yang mempunyai korelasi ketidak berhasilan KUBE dalam mengelola dan mengembangkan usaha ekonomi produktif dari faktor internal KUBE itu sendiri seperti :

a. Tingkat pengetahuan rendah

b. Ketrampilan berusaha tidak ada

c. Masalah fisik

d. Motivasi rendah

e. Kurang percaya diri

Uraian-uraian yang telah dipaparkan tersebut dapat disimpulkan sementara bahwa KUBE yang maju, berkembang dan gagal tergantung pada pendamping sosial dalam melakukan komunikasi interpersonal dengan anggota KUBE. Namun sejak tahun 1983 hingga 2013 belum pernah ada kajian atau penelitian yang menganalisis keberhasilan KUBE dalam mengembangkan usaha ekonomi produktif di tinjau dari sudut konsep komunikasi interpersonal Pendamping Sosial dengan anggota KUBE. Oleh karena itu dilakukan penelitian dengan judul " Pengaruh Komunikasi 
Volume 5 Nomor 1, April 2019

Interpersonal Pendamping Sosial Terhadap Kinerja Usaha Ekonomi Produktif di Kota Banjarmasin". Tujuan dari penelitian ini adalah untuk menguji dan menganalisis pengaruh komunikasi interpersonal Pendamping Sosial terhadap Kinerja Usaha Ekonomi Produktif di Kota Banjarmasin.

\section{METODE PENELITIAN}

Rancangan penelitian yang digunakan dengan pendekatan metode kuantitatif. Instrumen dalam penelitian ini menggunakan kuesioner atau angket untuk mengukur variabel komunikasi interpersonal pendamping sosial pendekatan kognitif (X1), pendekatan emosional (X2), dan pendekatan menyenangkan (X3) dan kinerja anggota KUBE dalam mengembangkan usaha ekonomi produktif $(\mathrm{Y})$. Jenis kuesioner yang digunakan adalah kuesioner tertutup.

Penelitian ini dilakukan di Kota Banjarmasin pada dua wilayah Kecamatan yaitu Kecamatan Banjarmasin Barat meliputi : Kelurahan Telaga Biru, Kelurahan Pelambuan, Kelurahan Kuin Selatan dan Kecamatan Banjarmasin Selatan meliputi : Kelurahan Basirih Selatan, Kelurahan Mantuil, Kelurahan Murung Raya yang ada Kelompok Usaha Bersama (KUBE).

Populasi penelitian ini adalah para pendamping sosial dan anggota KUBE yang pernah terlibat dalam hubungan komunikasi interpersonal di Kota Banjarmasin. Sampel dipilih dan ditentukan secara sengaja (purvosive). Berdasarkan tujuan penelitian ini, yakni untuk mengetahui pengaruh kemampuan komunikasi interpersonal pendamping sosial dengan anggota KUBE terhadap kinerja usaha ekonomi produktif di Kota Banjarmasin, Maka responden yang diambil sebagai berikut :

1. Pendamping sosial sebanyak 6 orang sesuai dengan jumlah yang ada

2. Anggota KUBE yang Maju sebanyak 11 orang dari 90 orang

3. AnggotaKUBE yang berkembang 10 orang dari 140 orang

4. Anggota KUBE yang gagal 10 orang dari 70 orang

Analisis data melalui Analisa Statistik, analisis deskriptif berfungsi untuk meringkas, mengklasifikasi, dan menyajikan data 
Volume 5 Nomor 1, April 2019

\section{HASIL PENELITIAN DAN PEMBAHASAN}

Penelitian ini dilakukan pada tanggal 8 Agustus sampai dengan tanggal 31 Agustus 2015, dengan sampel penelitian sebanyak 6 orang responden Pendamping Sosial dan 31 orang responden anggota Kelompok Usaha Bersama (KUBE).

\section{Tabel 1}

Distribusi Frekuensi Responden Pendamping Sosial

Menurut Jenis Kelamin

\begin{tabular}{ccc}
\hline Jenis Kelamin & Frekuensi & Prosentase (\%) \\
\hline Laki-laki & 2 & 33,3 \\
Perempuan & 4 & 66,7 \\
\hline Total & 6 & 100 \\
\hline
\end{tabular}

Sumber : Data Primer, 2016

Tabel di atas menunjukkan distribusi frekuensi responden pendamping sosial, berdasarkan jenis kelamin yaitu laki-laki sebanyak 2 orang responden $(33,3 \%)$ dan dan berjenis kelamin perempuan sebanyak 4 orang responden $(66,7 \%)$.

Tabel 2

Distribusi Frekuensi Responden Anggota Kelompok Usaha Bersama (KUBE) Menurut Jenis Kelamin

\begin{tabular}{ccc}
\hline Jenis Kelamin & Frekuensi & Prosentase (\%) \\
\hline Laki-laki & 20 & 64,5 \\
Perempuan & 11 & 35,5 \\
\hline Total & 31 & 100 \\
\hline
\end{tabular}

Sumber : Data Primer, 2016

Tabel di atas menunjukkan distribusi frekuensi responden anggota Kelompok Usaha bersama (KUBE) berdasarkan jenis kelamin yaitu laki-laki sebanyak 20 orang responden $(64,5 \%)$ dan berjenis kelamin perempuan sebanyak 11 responden $(35,5 \%)$.

Tabel 3

Distribusi Frekuensi Umur Respoden Pendamping Sosial

\begin{tabular}{ccc}
\hline Golongan Umur & Frekuensi & Prosentase (\%) \\
\hline $21-40$ tahun & 1 & 16,7 \\
$41-60$ tahun & 5 & 83,3 \\
$61-80$ tahun & 0 & 0 \\
\hline Total & 6 & 100 \\
\hline
\end{tabular}

Sumber : Data Primer, 2016 
Berdasarkan tabel di atas, dapat dilihat distribusi frekuensi responden pendamping sosial menurut golongan umur yaitu responden berumur 21 - 40 tahun sebanyak 1 orang $(16,7 \%)$ dan responden berumur $41-60$ tahun sebanyak 5 orang $(83,3 \%)$.

Tabel 4

Distribusi Frekuensi Responden Anggota

Kelompok Usaha Bersama (KUBE) Menurut Golongan Umur

\begin{tabular}{ccc}
\hline Golongan Umur & Frekuensi & Prosentase (\%) \\
\hline $21-40$ tahun & 10 & 32,2 \\
$41-60$ tahun & 21 & 67,8 \\
$61-80$ tahun & 0 & 0 \\
\hline Total & 31 & 100 \\
\hline
\end{tabular}

Sumber : Data Primer, 2016

Berdasarkan tabel di atas, dapat dilihat distribusi frekuensi responden Kelompok Usaha Bersama (Kube) menurut golongan umur yaitu responden berumur 21 - 40 tahun sebanyak 10 orang (33,3\%), dan responden berumur $41-60$ tahun sebanyak 21 orang $(67,8 \%)$ dan tidak ada responden yang berumur 61 - 80 tahun.

Tabel 5

Distribusi Frekuensi Respoden Pendamping Sosial Menurut Tingkat Pendidikan

\begin{tabular}{ccc}
\hline Tingkat Pendidikan & Frekuensi & Prosentase (\%) \\
\hline SD & 0 & 0 \\
SLTP & 0 & 0 \\
SLTA & 4 & 66,7 \\
DIII & 0 & 0 \\
S1 & 2 & 33,3 \\
\hline Total & 6 & 100 \\
\hline
\end{tabular}

Sumber : Data Primer, 2016

Tabel di atas menunjukkan bahwa proporsi pendidikanresponden pendamping sosial adalah sarjana (S1) sebanyak 2 orang $(33,3 \%)$ dan SLTA sebanyak 4 orang $(66,7 \%)$. 
Volume 5 Nomor 1, April 2019

Tabel 6

Distribusi Frekuensi Responden Anggota Kelompok Usaha Bersama (KUBE) Menurut Tingkat Pendidikan

\begin{tabular}{ccc}
\hline Tingkat Pendidikan & Frekuensi & Prosentase (\%) \\
\hline SD & 7 & 22,6 \\
SLTP & 8 & 25,8 \\
SLTA & 16 & 51,6 \\
DIII & 0 & 0 \\
S1 & 0 & 100 \\
\hline Total & 31 & 100 \\
\hline
\end{tabular}

Sumber : Data Primer, 2016

Tabel di atas menunjukkan bahwa tingkat pendidikan responden anggota Kelompok Usaha Bersama (KUBE) menurut proporsi pendidikan yang paling banyak adalah SLTA sebanyak 16 orang $(51,6 \%)$ sedangkan pendidikan SD sebanyak 7 orang $(23,3 \%)$ dan SLTP sebanayak 8 orang $(26,7)$

Tabel 7

Distribusi Frekuensi Respoden Pendamping Sosial Menurut Pekerjaan

\begin{tabular}{ccc}
\hline Pekerjaan & Frekuensi & Prosentase (\%) \\
\hline PNS & 0 & 0 \\
Pedagang & 0 & 0 \\
Wiraswasta & 6 & 100 \\
Buruh & 0 & 0 \\
\hline Total & 6 & 100 \\
\hline
\end{tabular}

Sumber : Data Primer, 2016

Tabel di atas menunjukkan bahwa pekerjaanresponden pendamping sosial adalah wiraswasta sebanyak 6 orang (100\%).

Tabel 8

Distribusi Frekuensi Responden Anggota Kelompok Usaha Bersama (KUBE) Menurut Pekerjaan

\begin{tabular}{ccc}
\hline Pekerjaan & Frekuensi & Prosentase (\%) \\
\hline PNS & 0 & 0 \\
Pedagang & 5 & 16,1 \\
Wiraswasta & 24 & 77,4 \\
Buruh & 2 & 6,5 \\
\hline Total & 31 & 100 \\
\hline
\end{tabular}

Sumber : Data Primer, 2016 
Tabel di atas menunjukkan bahwa pekerjaan responden anggota Kelompok Usaha Bersama (KUBE) menurut proporsi pekerjaan yang paling banyak adalah wiraswasta sebanyak 24 orang $(77,4 \%)$ sedangkan pedagang sebanyak 5 orang $(16,1$ $\%)$ dan buruh sebanyak 2 orang $(6,5 \%)$.

Analisis kemampuan komunikasi interpersonal pendamping sosial dengan anggota Kelompok Usaha Bersama dari pendekatan Kognitif meliputi :

Tabel 9

Distribusi Frekuensi Responden Pendamping Sosisal Berdasarkan Pendekatan Kognitif

\begin{tabular}{ccc}
\hline Pendekatan Kognitif & Jumlah & Prosentase (\%) \\
\hline Sangat Setuju & 5 & 83,3 \\
Setuju & 1 & 16,7 \\
Kurang Setuju & 0 & 0 \\
Tidak Setuju & 0 & 0 \\
Sangat Tidak Setuju & 0 & 0 \\
\hline Jumlah & 6 & 100 \\
\hline
\end{tabular}

Sumber : Data Primer, 2016

Berdasarkan tabel 9 didapatkan bahwa responden pendamping sosial yang melakukan komunikasi interpersonal dengan anggota kelompok bersama (KUBE) ternyata yangmelakukan pendekatan kognitif sangat setuju sebanyak 5 responden $(83,3$ $\%)$ dan setuju sebanyak 1 responden $(16,7 \%)$.

Tabel 10

Distribusi Frekuensi Responden Pendamping Sosisal Berdasarkan Pendekatan Emosional

\begin{tabular}{ccc}
\hline Pendekatan Emosional & Jumlah & Prosentase (\%) \\
\hline Sangat Setuju & 3 & 50 \\
Setuju & 3 & 50 \\
Kurang Setuju & 0 & 0 \\
Tidak Setuju & 0 & 0 \\
Sangat Tidak Setuju & 0 & 0 \\
\hline Jumlah & 6 & 100 \\
\hline
\end{tabular}

Sumber : Data Primer, 2016

Berdasarkan tabel 10 didapatkan bahwa responden pendamping sosial yang melakukan komunikasi interpersonal dengan anggota kelompok bersama (Kube) 
Volume 5 Nomor 1, April 2019

ternyata yang menilai melakukan pendekatan emosional sangat setuju sebanyak 3 responden $(50 \%)$ dan setuju 3 responden $(50 \%)$.

Tabel 11

Distribusi Frekuensi Responden Pendamping Sosial Berdasarkan Pendekatan Menyenangkan

\begin{tabular}{ccc}
\hline Pendekatan Menyenangkan & Jumlah & Prosentase (\%) \\
\hline Sangat Setuju & 3 & 50 \\
Setuju & 3 & 50 \\
Kurang Setuju & 0 & 0 \\
Tidak Setuju & 0 & 0 \\
Sangat Tidak Setuju & 0 & 0 \\
\hline Jumlah & 6 & 100 \\
\hline
\end{tabular}

Sumber : Data Primer, 2016

Berdasarkan tabel 11 didapatkan bahwa responden pendamping sosial yang melakukan komunikasi interpersonal dengan anggota kelompok bersama (Kube) ternyata yang menilai melakukan pendekatan menyenangkan sangat setuju sebanyak 3 responden $(50 \%)$ dan setuju sebanyak 3 responden $(50 \%)$.

Tabel 12

Distribusi Frekuensi Responden Anggota kelompok Bersama (KUBE) Berdasarkan Pendekatan Kognitif

\begin{tabular}{ccc}
\hline Pendekatan Kognitif & Jumlah & Prosentase (\%) \\
\hline Sangat Setuju & 7 & 22,6 \\
Setuju & 24 & 77,4 \\
Kurang Setuju & 0 & 0 \\
Tidak Setuju & 0 & 0 \\
Sangat Tidak Setuju & 0 & 0 \\
\hline Jumlah & 31 & 100 \\
\hline
\end{tabular}

Sumber : Data Primer, 2016

Berdasarkan tabel 12 didapatkan bahwa responden anggota kelompok bersama (KUBE) menyatakan untuk pendekatan kognitif sangat setuju sebanyak 7 responden $(22,6 \%)$ dan sebanyak 24 responden $(77,4 \%)$. 
Volume 5 Nomor 1, April 2019

Tabel 13

Distribusi Frekuensi Responden Anggota kelompok Bersama (KUBE) Berdasarkan Pendekatan Emosional

\begin{tabular}{ccc}
\hline Pendekatan Emosional & Jumlah & Prosentase (\%) \\
\hline Sangat Setuju & 3 & 9,7 \\
Setuju & 24 & 77,4 \\
Kurang Setuju & 4 & 12,9 \\
Tidak Setuju & 0 & 0 \\
Sangat Tidak Setuju & 0 & 0 \\
\hline Jumlah & 31 & 100 \\
\hline
\end{tabular}

Sumber : Data Primer, 2016

Berdasarkan tabel 13 didapatkan bahwa responden anggota kelompok bersama (KUBE) menyatakan untuk pendekatan emosional sangat setuju sebanyak 3 responden $(9,7 \%)$, setuju sebanyak 24 responden $(77,4 \%)$ dan kurang setuju sebanyak 4 responden $(12,9 \%)$.

Tabel 14

Distribusi Frekuensi Responden Anggota kelompok Bersama (KUBE)

Berdasarkan Pendekatan Menyenangkan

\begin{tabular}{ccc}
\hline Pendekatan Kognitif & Jumlah & Prosentase (\%) \\
\hline Sangat Setuju & 6 & 19,4 \\
Setuju & 18 & 58,1 \\
Kurang Setuju & 7 & 22,5 \\
Tidak Setuju & 0 & 0 \\
Sangat Tidak Setuju & 0 & 0 \\
\hline Jumlah & 31 & 100
\end{tabular}

Sumber : Data Primer, 2016

Berdasarkan tabel 14 didapatkan bahwa responden anggota kelompok bersama (KUBE) menyatakan untuk pendekatan menyenangkan sangat setuju sebanyak 6 responden (19,4\%), setuju sebanyak 18 responden $(58,1 \%)$ dan kurang setuju sebanyak 7 responden $(22,5 \%)$.

\section{Analisis Bivariat}

\section{Uji Validitas}

Dari tabel hasil uji validitas memperlihatkan nilai $r$ hitung setiap indicator varibael pendekatan koginitif, pendekatan emosional, dan pendekatan meneyanangkan 
lebih besar dibanding nilai $\mathrm{r}$ tabel.Dengan demikian indicator atau kuesioner yang digunakan masing-masing variabel dinyatakan valid untuk digunakan sebagai alat ukur variabel.

\section{Uji Reliabilitas}

Secara keseluruhan hasil uji reliabilitas dapat dilihat hasilnya pada tabel berikut:

Tabel 15

Hasil Uji Reliabilitas

\begin{tabular}{llc}
\hline No. & \multicolumn{1}{c}{ Variabel } & Cronbach Alpha \\
\hline 1. & Pendekatan Koginitif & 0,943 \\
2. & Pendekatan emosional & 0,845 \\
\hline 3. & Pendekatan menyenangkan & 0,845 \\
\hline
\end{tabular}

Sumber : data primer diolah 2016

Dapat dinyatakan bahwa semua item pernyataan dari angket tersebut adalah reliabel dengan demikian item pernyataan pada variabel tersebut reliabel menjadi pembentuk konstruk. Nilai Cronbach Alpha semua variabel lebih besar dari 0,60 sehingga dapat disimpulkan indikator atau kuesioner yang digunakan semua dinyatakn handal atau dapat dipercaya sebagai alat ukut variabel.

\section{Teknik Analisis Data}

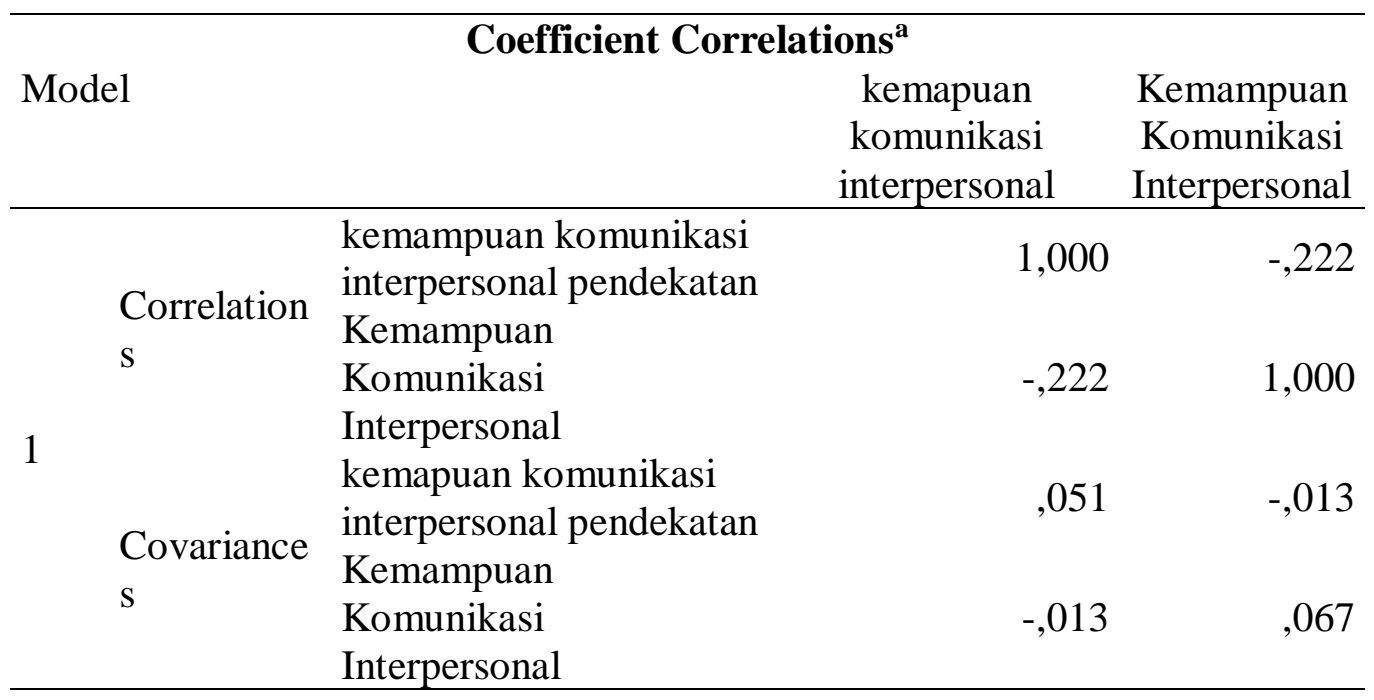

a. Dependent Variable: Perkembangan kube 
Volume 5 Nomor 1, April 2019

Persamaan regresi di atas dapat dijelaskan sebagai berikut : dari data di atas secara pendekatan kognitif diketahui bahwa besarnya koefisien korelasi (R) sebesar 1,000, maka dapat dinyatakan bahwa pengaruh kemampuan komunikasi interpersonal pendamping sosial dengan kinerja usaha ekonomi produktif Anggota Kelompok Usaha Bersama (Kube) di Kota Banjarmasin secara simultan adalah positif.

\section{Analisis Korelasi Ganda (R)}

Dari hasil regresi, lihat otput model summary dan disajikan sebagai berikut :

Tabel 16

Hasil Analisis Korelasi Ganda

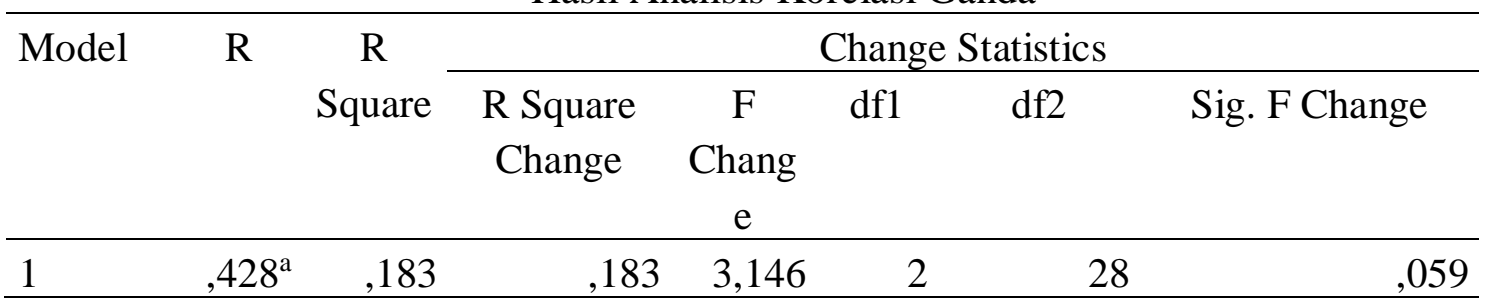

Berdasarkan tabel di atas diperoleh angka $\mathrm{R}$ sebesar 0,428. Hal ini menunjukkan bahwa terjadi pengaruh yang sangat kuat antara kemampuan komunikasi interpersonal pendamping sosial terhadap kinerja usaha ekonomi produktif Kelompok Usaha Bersama ( KUBE).

\section{AnalisisDeterminasi $\left(\left(\mathbf{R}^{2}\right)\right.$}

Dari hasil analisis regresi. Lihat pada output model summary dan disajikan sebagai berikut:

\begin{tabular}{|c|c|c|c|c|c|c|c|c|c|}
\hline \multirow{4}{*}{ Model } & \multirow{4}{*}{$\mathrm{R}$} & \multirow{4}{*}{$\begin{array}{c}\mathrm{R} \\
\text { Square }\end{array}$} & \multirow{4}{*}{$\begin{array}{l}\text { Adjust } \\
\text { ed R } \\
\text { Square }\end{array}$} & \multicolumn{6}{|c|}{ Model Summaryb } \\
\hline & & & & Std. Error & & Change & Stati & stics & \\
\hline & & & & of the & $\mathrm{R}$ & & df1 & df2 & Sig. F \\
\hline & & & & Estimate & $\begin{array}{l}\text { Square } \\
\text { Change }\end{array}$ & Change & & & Change \\
\hline 1 & ,428 &, 183 &, 125 & ,615 & , 183 & 3,146 & 2 & 28 & 059 \\
\hline
\end{tabular}

a. Predictors: (Constant), kemapuan komunikasi interpersona,

Berdasarkan tabel di atas diperoleh angka $\mathrm{R}^{2}$ ( $\mathrm{R}$ Square) sebesar 0, 183 atau (18,3\%). Hal ini menunjukkan bahwa prosentase sumbangan pengaruh variabel independen (kemampuan komunikasi interpersonal pendamping sosial) terhadap 
variabel dependen (perkembangan usaha ekonomi produktif KUBE) sebesar 18,3\%. Atau variasi variabel independen yang digunakan dalam model ((kemampuan komunikasi interpersonal pendamping sosial) mampu menjelaskan sebesar 18,3\% variasi varaibel dependen (kinerja usaha ekonomi produktif KUBE). Sedangkan sisanya sebesar $81,7 \%$ dipengaruhi atau dijelaskan oleh variabel lain yang tidak dimasukkan dalam model penelitian ini.

Adjusted $R$ Squareadalah nilai $R$ Squareyang telah disesuaikan, nilai selalu lebih kecil dari $R$ Squaredan angka ini bisa memiliki harga negatif. Menurut Santoso (2001) bahwa untuk regresi dengan lebih dari dua variabel bebas digunakan Adjusted $R^{2}$ sebagai koefisien determinasi.

Standard Error of the Estimate adalah suatu ukuran banyaknya keslaahan model regresi dalam memperediksikan nilai Y. Dari hasil regresi didapat nilai 615 (variabel), hal ini berarti banyaknya keslaahan dalam prediksi kinerja usaha ekonomi produktif KUBE lebih kecil sebesar 615 Sebagai pedoman jika Standard Error of the Estimate kurang dari standar deviasi $Y$, maka model regresi semakin baik dalam memprediksi nilai Y.

\section{Uji Koefisien Regresi Secara Bersama-sama (Uji F)}

Dari hasil output analisi regresi dapat diketahui nilai F seperti pada tabel berikut ini :

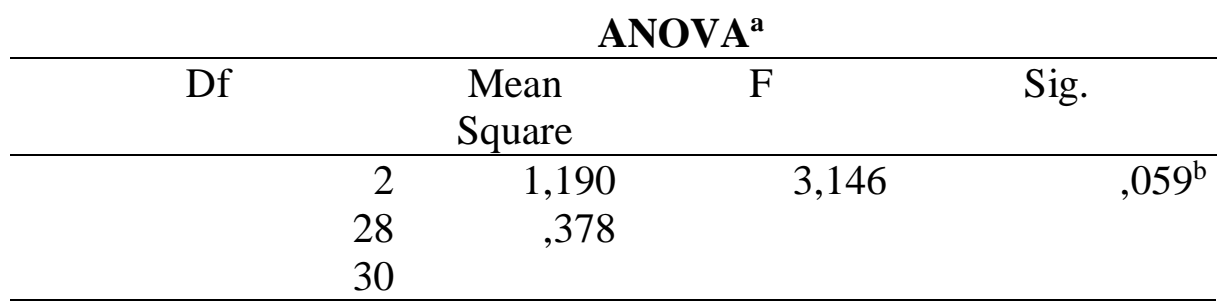

a. Dependent Variable: Kinerja usaha ekonomi produktif kube

b. Predictors: (Constant), kemampuan komunikasi interpersoalf

Dari tabel di atas diketahui bahwa F hitung 3,146> F 0,05. Dengan demikian pengaruh kemampuan interpersonal pendamping sosial secara simultan berpengaruh signifikan terhadap kinerja usaha ekonomi produktif KUBE. Adapun besarnya pengaruh dapat dilihat dari koefisien determinasi $\left(R^{2}\right)=0,183$ artinya 18,3 $\%$. Sisanya $81,7 \%$ dipengaruhi faktor lain. 


\section{Uji Koefisien Regresi Secara Parsial (Uji}

Dari hasil analisis regresi output dapat disajikan sebagai berikut:

\begin{tabular}{llrr}
\hline Model & \multicolumn{1}{c}{$\begin{array}{c}\text { kemapuan } \\
\text { komunikasi } \\
\text { interpersonal }\end{array}$} & $\begin{array}{c}\text { Kemampuan } \\
\text { Komunikasi } \\
\text { Interpersonal }\end{array}$ \\
\hline \multirow{2}{*}{ Correlations } & $\begin{array}{l}\text { kemampuan komunikasi } \\
\text { interpersonal pendekatan } \\
\text { Kemampuan Komunikasi }\end{array}$ & 1,000 &,- 222 \\
& $\begin{array}{l}\text { Interpersonal } \\
\text { kemapuan komunikasi } \\
\text { interpersonal pendekatan }\end{array}$ &,- 222 & 1,000 \\
Kemampuan Komunikasi &, 051 &,- 013 \\
& Interpersonal &,- 013 &, 067 \\
\hline
\end{tabular}

a. Dependent Variable: Perkembangan kube

Dari tabel di atas dinyatakan model regresi yang digunakan bahwa t hitung parameter b1 sebesar 0,67 Kaidah keputrusan dinyatakan bahwa t hitung $<\mathrm{t}$ Tabel. Sehingga secara parsial kemampuan komunikasi interpersonal signifikan terhadap kinerja usaha ekonomi produktif KUBE.

\section{PEMBAHASAN}

Hasil uji analisis data menunjukkan bahwa nilai sig atau significanceadalah $0,000<0,05$. Oleh karena itu nilai probabilitas dibawah 0,05 maka Ho diitolak, Hal ini berarti bahwa kemampuan komunikasi interpersonal pendamping sosial mempunyai pengaruh yang signifikan terhadap perkembangan usaha ekonomi produktif Kelompok Usaha Bersama (KUBE).

Di dalam pendampingan sosial komunikasi antar pribadi ini terjadi antara pendamping sosial dengan anggota KUBE dalam rangka membicarakan masalahmasalah yang dihadapi kelompok seperti masalah usaha ekonomi produktif, organisasi dan social secara komunikasi interpersonal berpengaruh tehadap kinerja usaha ekonomi produktif Kelompok Usaha Bersama (KUBE) tersebut.

Berdasarkan informasi yang diadapatkan peneliti dilapangan menunjukkan bahwa komunikasi interpersonal atau komunikasi antar pribadi adalah suatu proses penyampaian pesan baik secara langsung maupun tidak langsung, secara lisan maupun tulisan sehingga kedua pihak yang berkomunikasi memperoleh makna pesan yang sama 
sangat berpengaruh terhadap kinerja usaha ekonomi anggota Kelompok Usaha Bersama (KUBE).

Menurut pendapat Ife (1995), peran pendamping sosial umumnya mencakup tiga peran utama, yaitu: fasilitator, pendidik, perwakilan masyarakat, dan peran-peran teknis bagi masyarakatyang didampinginya. Pendampingan adalah membantu masyarakat baik individu maupun kelompok untuk menemukan kemampuan yang ada pada diri mereka dan kemungkinan mereka agar mendapat kecakapan untuk mengembangkan kemampuan itu.

Dalam hal ini pendampingan dilakukan demi untuk kepentingan orang yang didampingi bukan kepentingan orang yang mendampingi atau mencari keuntungan demi kepentingan diri sendiri.Ia adalah orang netral yang bertugas untuk memperlancar proses berkelompok dalam mencapai tujuannya.

Pendamping sosial mengatur bagaimana anggota kelompok berkomunikasi, berdiskusi, bekerjasama, dan lain-lain. Sementara tujuan atau isi yang dibicarakan, didiskusikan, diputuskan dan ingin dicapai, melakukan identifikasi dan analisa masalah, merencanakan kegiatan, monitoring dan evaluasi bersama dengan kelompok sasaran lalu mendorong masyarakat untuk melakukan perubahan-perubahan sikap, pengetahuan maupun perilaku baik perubahan secara individual maupun kelompok.

\section{KESIMPULAN}

1. Secara parsial kemampuan komunikasi interpersonal pendamping KUBE tidak signifikan terhadap kinerja usaha ekonomi produktif yang di laksanakan oleh anggota KUBE.

2. Pengaruh antara kemampuan komunikasi interpersonal pendamping sosial dengan anggota Kelompok Usaha Bersama (KUBE) dalam mengembangkan usaha ekonomi produktif di Kota Banjarmasin melalui pendekatan emosional terdapat pengaruh parsial kemampuan komunikasi interpersonal pendamping sosial tidak signifikan terhadap perkembngan usaha ekonomi usaha produktif anggota KUBE.

3. Hubungan antara kemampuan komunikasi interpersonal pendamping sosial dengan anggota Kelompok Usaha Bersama (KUBE) dalam mengembangkan usaha ekonomi produktif di Kota Banjarmasin melalui pendekatan menyenangkan kemampuan 
Volume 5 Nomor 1, April 2019

komunikasi interpersonal pendamping sosial secara simultan berpengaruh signifikan terhadap perkembangan usaha ekonomi usaha produktif anggota KUBE.

\section{DAFTAR PUSTAKA}

Ardianto, Elvinaro, 2010, Metode Penelitian Untuk Publik Relations: Kuantitatif dan Kualitatif, Bandung, Simbiosa Rekatama Media.

Buku Saku Pendamping, Dinas Sosial Provinsi Kalimantan Selatan Tahun 2014

Cangara, Hafidz, 2005, Pengantar Ilmu Komunikasi, Jakarta, PT Raja Grafindo Persada

Kuswarno, Engkus, 2008, Etnografi Komunikasi: Suatu Pengantar dan Contoh Penelitiannya, Bandung, Widya Padjadjaran.

Mulyana, Deddy, 2001, Ilmu Komunikasi, Suatu Pengantar, Bandung, Rosda Karya.

Rakhmat, Jalaluddin, 2005, Psikologi Komunikasi, Bandung, Remaja Rosdakarya.

Effendy, Onong, Uchjana, Komunikasi Teori dan Praktek, Bandung, Remaja Rosdakarya

Cangara, Hafidz, 2005, Pengantar Ilmu Komunikasi, Jakarta, PT Raja Grafindo Persada

Littlejohn, Stephen W, 2001, Theories of Human Communication, USA, Wadsworth Publishing 